\title{
GUEST EDITORIAL Rapid motorization in Asian cities: urban transport infrastructure, spatial development and travel behavior
}

\author{
Ryuichi Kitamura · Jamilah Mohamad
}

Published online: 16 April 2009

(C) Springer Science+Business Media, LLC. 2009

Transport infrastructure has played an indispensable role in the growth of urban societies. During the first half of the 20th century transport, particularly rail, was seen as asserting a powerful influence on economic growth and industrial location. The concentration of employment in, or close to, city centers produced radial commuting patterns with traffic flows concentrated along rail, tram and bus routes. Changes in the nature of industrial activities or within urban communities are followed by changes in transport requirements. Hence, land use patterns and built environments in turn shape the demand for travel. Because of this inter-dependency, it is important to note that carefully-integrated and coordinated transportation and urban development is essential to ensuring a sustainable future, not only in an environmental sense, but socially and economically as well.

Opportunities for personal mobility have dramatically improved since the 1950s, firstly in the developed countries, with increasing car ownership levels. Patterns of personal movements reflect the influences of mobility and accessibility levels. New transport infrastructure generates new demand for travel, new roads generate faster and longer trips, more trips by car and higher car ownership, all of which adds up to more traffic congestion. In the modern city development today, several factors interact to create a much more diverse situation with trips occurring across cities and from inner to outer areas. Decentralization policies have led to relocation of older inner-city enterprises into peripheral estates, aided by the car.

Schwanen et al. (2001) maintained that metropolitan areas, both in old industrial countries and in developing countries, have evolved from mono-centric structures into poly-centric urban forms. However, they noted that literature on how mono-centric and poly-centric metropolitan structures affect travel behavior is polarized. The work of Schwanen et al. 2001 summarized the conclusions obtained from research undertaken in

Ryuichi Kitamura-Deceased.

R. Kitamura

Department of Urban Management, Kyoto University, Kyoto, Japan

J. Mohamad $(\bowtie)$

Department of Geography, University of Malaya, Kuala Lumpur, Malaysia

e-mail: jamilahmd@um.edu.my; jamilahmd1@yahoo.com 
this area. Some authors (e.g., Gordon and Richardson 1997; Levinson and Kumar 1994) suggest that a de-concentrated structure tends to reduce commuting distance and commuting times. Scholars in this group adhere to the 'co-location' hypothesis, which states that firms and households periodically readjust spatially to achieve balanced average commuting distances and duration. Other authors (Cervero 1996; Newman and Kenworthy 1989; Ewing 1997) refute this positive view of the effect of poly-centricity on travel behavior and suggested that decentralization of firms and households has been a disaster for travel behavior. In terms of commuting times, Gordon et al. (1989) have found shorter commuting times for suburban residents than for central-city residents in metropolitan areas with at least three million inhabitants. Because of the stronger congestion effects in high-density mono-centric cities, travel times are higher there than in low-density suburban communities in poly-centric cities. Giuliano and Small (1993) pointed out that a polycentric pattern of employment centers has a potential for shorter commuting times. Meanwhile, Cervero and Landis (1991) research results suggested that, although overall commuting times and distances may be stable or fall over time, the process of job decentralization may have increased the variation between individual workers. Cervero (1996) maintained that urban development, led by rising affluence, advancing technologies, and other mega-forces, had transformed from a predominant mono-centric form wellsuited to point-to-point rail systems to poly-centric forms more conducive to the car and undermining the use of public transport.

Even though in general car ownership levels are relatively low in developing countries, they are rising very rapidly. To compound matters, car ownership is heavily concentrated in their capital cities. Taking the poor quality of the transport infrastructure in these countries, accompanied by decreasing levels of personal safety and widespread pollution, it can be readily seen that the urban transport problem is at its most intractable in the cities of the developing countries. Pendyala and Kitamura (2007) in initiating the special issue of Transportation to address the issue of rapid motorization in countries of South and East Asia expressed alarm over the explosive growth in vehicle ownership and utilization in rapidly developing Asian economies. They both hoped that the 2007 issue would help to identify some key forces driving the motorization trend and pave the way towards understanding the implications of the trend for future sustainable development in the Asian cities. This present issue of Transportation aims to build on further the understanding and the implications of the motorization trend, this instance mainly tackling the issues faced in Kuala Lumpur, capital city of Malaysia as well as the provincial city of George Town, Penang and drawing comparisons with the Kei-Han-Shin (Kyoto-Osaka-Kobe) region in Japan. The five papers that made up this issue are the result of a collaborative effort under the Japan Society for the Promotion of Science (JSPS)-VCC program between the two countries which runs from 2000 to 2009. It is hoped that the special issue will address the dearth of literature on the subject matter of transportation and urban development in Kuala Lumpur.

Tolley and Turton (1995) noted that a shift in demand in the advanced societies is provided by the decline of public transport in the face of steadily rising car ownership. Public transport fares are kept low and raising fares is almost impossible. The attempts made to meet mobility needs are thus seen as a 'welfare service', resulting in a lack of funds for new projects and finance for maintaining old and unreliable vehicles, so that services cannot keep pace with growth in demand. Those services which are operated are seriously affected by congestion due to inadequate road space, bad traffic management and mixed traffic. In the first paper of this issue, A.T. Kiggundu examined this in the developing country context of Malaysia. The city of Kuala Lumpur occupies an area of 243 sq.km with a population of 1.6 million people. The Kuala Lumpur city, together with 
its conurbation, is the most industrialized and the fastest-growing economic region in Malaysia. Although the city of Kuala Lumpur has a population of 1.6 million, about four million are living within the Kuala Lumpur Conurbation (KLC). Kiggundu noted that the Government has remained as a key source of funding for the public transport sector in Kuala Lumpur, Malaysia due to the failure of major public transport operators to secure ample funding. The low levels of public transport use in Kuala Lumpur are attributed to the high rates of private vehicle ownership.

Among the major approaches adopted in Kuala Lumpur are public sector financing, private concessions and bus franchising. Kiggundu explained that the increasingly interventionist policy stance by the government is due to deficiencies in the performance of privately-owned and financed public transport companies, although this necessarily places an additional burden on Government coffers. Before the introduction of private concessions, bus franchising was the main source of funding for public transport in Kuala Lumpur. The Government introduced private concession procurement in mid 1980s and this experiment literally turned Kuala Lumpur into a laboratory for private sector participation in infrastructure development including toll expressways and public transport systems. Research by the World Bank seems to indicate that the three rail concessions in Kuala Lumpur had achieved much despite lacking a good enabling environment. The World Bank is of the view that partnerships between the private sector and the Government should be formed to solve the financing and investments risks associated with such venture. A challenge noted by Kiggundu has to do with the current low-density land use patterns as well as the existence of few transit-oriented high density developments in Kuala Lumpur. Suburbanization and urban decentralization have created small and scattered markets that are difficult and costly to serve by fixed route public transport systems. The author draws on innovative solutions from Tokyo and Hong Kong, notable amongst which is the value capture financing system. Under this system, the increment in land and property values brought about by the accessibility of public transport is exploited by public transport operators to diversify their sources of revenue and to pay for capital costs. Tama New Town is cited as a case in point. Another crucial financing strategy is the public-private sector partnerships. By applying such partnerships, policy makers in Kuala Lumpur would be able to mitigate both commercial and non-commercial risks associated with the implementation of transport infrastructure projects. Although Kiggundu is optimistic about the future, he noted that in both cities of Hong Kong and Tokyo, public transport systems were developed before private vehicles use became pervasive. This is certainly not the case for Kuala Lumpur as we shall see in the comparative perspective offered by the paper written by Senbil, Kitamura and Mohamad in this issue.

While the bus public transport system faces an uphill task in keeping to journey schedules due to the intense competition for road space vis-à-vis the increasing volumes of private vehicles, the author of the second paper hoped that rail-based public transport would be able to offer a viable alternative mode of transport for the commuters in Kuala Lumpur. Abdul-Hamid carried out a study on utilization patterns of park-and-ride facilities amongst Kuala Lumpur commuters in April 2005. The study was undertaken to analyze the demand and supply of the rail-based park-and-ride facilities of two commuter stations (namely Shah Alam and Seremban) located at the fringe of the Kuala Lumpur Conurbation (the KLC). The analysis was done based on utilization (occupancy rate), accumulation and duration pattern of those who parked at the stations. The study found out that both stations show a relatively good level of utilization (occupancy rate) of between 80 and $95 \%$. The majority of parkers at both stations are long-term parkers. However, in contrast to the rather active in-vehicle and out-vehicle $16 \mathrm{~h}$ flow pattern of the Shah Alam station, the 
Seremban station only saw an active $2 \mathrm{~h}$ in-vehicle and out-vehicle flow only from 05:30 to 07:30 am. Beyond this time, vehicles began to accumulate and reached its peak at 10:30 am with 190 vehicles. This pattern of early morning peak accumulation is also seen in the case of the Calgary rail parking facility. The stations in the north-western part of Calgary also achieved an average weekday utilization rate of between $80 \%$ to even $100 \%$ reflecting the relatively high demand for the use of the park-and-ride facility during the weekdays. The results of Abdul-Hamid's study are comparable to results of similar studies in Seoul (East Asia), Calgary (Canada), Germany (Western Europe) and Tyne and Wear (UK) with regards to patterns of the use of park-and-ride facilities in terms of vehicle accumulation, parking duration and also utilization pattern. By monitoring and measuring the usage patterns of the park-and-ride facilities, transport planners can enhance their knowledge in the form of better indicators of the parking demand of an area. Since factors of parking availability and easy accessibility are important factors that have influence on the behavior of a park-and-ride user, more accurate information relating to the supply and demand of the parking facility will inevitably assist in the planning of new transport infrastructure.

Next, in A.S. Hassan's paper we have the example of the legacies of the British colonial rule in George Town, Penang, Malaysia and its influence on city layout and transport access. The British had adopted the concept of gridiron layout in town planning in America and Australasia from the model of the primary Roman colonies. The Romans had earlier copied from the Greek town planners and had later upgraded the pattern by adding two primary streets which were referred to as Cardo and Decumanus. George Town had a city layout divided into eight primary zones. Under the 'divide and rule' concept, the immigrants were placed to the allocated settlement zones based on their ethnic backgrounds. Each zone was perimetered with street borders to separate one from the other. In the early phase of development, Indian traders from Southern India were the first immigrants to be settled in the portcity followed by Indian Muslims, and later the Malays coming from Malay archipelagos especially Bugis and Acehnese. The establishment of the Chinese trading communities was to come later when they were attracted to the abundant commodities traded. Today, the Cardo and Decumanus still persist in the city of George Town, Penang. Beach Street was designed to serve as a primary North-South transport access (Cardo) with jetties built along the street for trading activities whereas Light Street serves as a primary East-West transport access (Decumanus). The 'divide and rule' concept of the zoning system enabled the British to govern George Town without facing major racial issues. Hence in this third paper, Hassan managed to show that the 'divide and rule' concept is an influential factor that had created the irregular gridiron layout in the inner city of George Town.

In the fourth paper of this issue, Senbil, Kitamura and Mohamad offered a comparative perspective of the situation in a developed Asian economy and a developing South East Asian economy. The paper attempts to shed light on the relationships among residential location, vehicle ownership, and mobility in two metropolitan areas of Kei-Han-Shin (KHS) and Kuala Lumpur (KL). The KHS metropolitan area developed in the first half of the 20th century along railway networks whose development strategies included development of residential subdivisions, shopping malls, and other real estate which served as trip generators and attractors around railway stations to reduce financial risks associated with such development and to secure stable rail ridership. Trends have changed in the postwar era with motorization, urbanization has now extended to outlying areas, resulting in residents being more auto-oriented. Despite that, enhanced train services that run on densely-developed rail networks provide ubiquitous access within the metropolitan core. Similarly, rapid economic growth in the KL metropolitan area has given rise to significantly accelerated urbanization. However, little investment prior to the 1980s for rail 
infrastructure resulted in a car-dominated society fueled by increased affluence and sprawling urbanization.

Their research conclude that, although households in the two locales on average allocate approximately equal amount of time to travel per household member, there are distinct differences between the two. The cumulative investment into public transport has enabled higher levels of mobility in the KHS metropolitan area as compared to the KL metropolitan area. While the KHS area exhibit tendencies that are consistent with the commonly accepted hypothesis (higher density and lower auto ownership in the centre, and decreasing density and increasing auto ownership towards the fringe), the KL area has revealed different tendencies. Residential location is likely the result of multiple decisions taken together (emphasis on affordability of residential units which is important in developing countries) rather than simply a conscious effort to reduce travel time expenditure. Senbil et al. note that the evolution of a metropolitan area may be unique and path-dependent, being heavily influenced by the history and culture of the locale, spatial and physical constraints, and historical progression in infrastructure development.

These findings are enhanced further by the work of Yamamoto whose results of study are elaborated in the fifth and final paper. In his study, the effects of the built environment on vehicle ownership are investigated. Yamamoto uses the same data set for Osaka and Kuala Lumpur to represent what he considered are possible likely scenarios for Asian developing countries in the future. The focus of his study is more on the interactions among vehicle ownership of different types. Rail was found to have a significantly larger modal share than bus in the Osaka Metropolitan Area, while rail share is significantly smaller in Kuala Lumpur. This is due to differences in rail networks between the two areas. Osaka has a dense rail network while Kuala Lumpur is just adding up to the basic rail services at the time of study. Bicycle has a larger modal share than motorcycle in Osaka while remaining smaller in Kuala Lumpur. Bicycle is mainly owned and used in zones of high population in Osaka, while it is used by those in zones of low population in Kuala Lumpur, which is partly due to the lack of rail coverage. Income is confirmed as a dominant factor determining vehicle, especially car, ownership in Kuala Lumpur. Yamamoto concluded his study by suggesting that multinomial logit models better represent the structure of vehicle bundle ownership including car, motorcycle and bicycle rather than trivariate binary probit model. Urban development policy measure such as higher density development may influence household vehicle ownership behavior, while provision of sufficient rail network may be the key to encourage further the change in vehicle ownership behavior.

It is clear from the discussion carried out in the five papers that the trend of motorization has become a critical issue in Kuala Lumpur as elsewhere in the rapidly-developing economies of Asia. In carrying out their daily activities, the urban population have to fulfill their daily mobility needs and the existing public transport facilities are not adequate, both in quality and quantity, to fulfill the demand. This emphasizes the need for greater attention from the Government to support a public transport-friendly policy. Dimitrou (2006) has argued that, thus far, no effective sustainable alternative to motorization has been offered to the cities of Asia. Massive investments in roads and highways and intense competition in the motor vehicle market has created the perfect setting for the rapid increase in private vehicle ownership and utilization across Asia. Further issues of Transportation would do well to take up this challenge to further the discourse on the motorization dilemma faced by the developing countries. 


\section{References}

Cervero, R.: Jobs-housing balance revisited: trends and impacts in the San Francisco bay area. J. Amer. Plann. Assoc. 62, 492-511 (1996)

Cervero, R., Landis, J.: Suburbanization of jobs and the journey to work. Working Paper, No. 83. The University of California Transportation Center, Berkeley (1991)

Dimitrou, H.T.: Towards a generic sustainable urban transport strategy for middle-sized cities in Asia: lessons from Ningbo, Kanpur and Solo. Habitat. Int. 30, 1082-1099 (2006)

Ewing, R.: Is Los Angeles-style sprawl desirable? J. Amer. Plann. Assoc. 63, 107-126 (1997)

Giuliano, G., Small, K.A.: Is the journey to work explained by urban structure? Urban. Stud. 30, 1485-1500 (1993)

Gordon, P., Richardson, H.W.: Are compact cities a desirable planning goal? J. Amer. Plann. Assoc. 63, 95106 (1997)

Gordon, P., Kumar, A., Richardson, H.W.: Congestion, changing metropolitan structure and city size in the United States. Int. Reg. Sci. Rev. 12, 45-56 (1989)

Levinson, D.M., Kumar, A.: The rational locator: why travel times have remained stable. J. Amer. Plann. Assoc. 60, 319-332 (1994)

Newman, P.W.G., Kenworthy, J.R.: Gasoline consumption and cities: a comparison of US cities in a global survey. J. Amer. Plann. Assoc. 55, 24-36 (1989)

Pendyala, R.M., Kitamura, R.: The rapid motorization of Asia: implications for the future-guest editorial. Transportation. 34, 275-279 (2007)

Schwanen, T., Dieleman, F.M., Dijst, M.: Travel behaviour in Dutch monocentric and polycentric urban systems. J. Transp. Geogr. 9, 173-186 (2001)

Tolley, R., Turton, B.: Transport Systems, Policy and Planning: A Geographical Approach. Longman Group Ltd., Harlow (1995)

\section{Author Biographies}

Ryuichi Kitamura, who died on 19 February 2009, was a professor of transportation specializing in the analysis and modeling of activity and travel behavior, assessment of transport policies, travel survey methods, and the impacts of the built environment on travel behavior. His research focused on the dynamics of human travel demand to explore the consequences of changing social and economic factors. He received the 2006 International Association for Travel Behavior Research Lifetime Achievement Award. He was an Editor of Transportation.

Jamilah Mohamad is professor and head of the Department of Geography, University of Malaya, Kuala Lumpur. Her main fields of research interest are travel behavior, the relationship between transport and spatial development and urban growth management, and is currently coordinating research at the SpatialEnvironmental Governance for Sustainability centre at the university. Jamilah receives her Ph.D. from the Department of City and Regional Planning, University of Cardiff, United Kingdom. 